\title{
ANALISIS REKRUTMEN DAN SELEKSI KARYAWAN PT. PANCARAN BELANTARA INDAH
}

Rekrutmen, Seleksi,

\author{
Andini Triana Dewi \\ andinitd@gmail.com \\ Tri Diana \\ tridiana@gmail.com
}

Akademi Manajemen Perusahaan Panca Bhakti Pontianak

\begin{abstract}
Abstrak: Sumber Daya Manusia merupakan salah satu bagian terpenting dalam sebuah organisasi atau perusahaan untuk mencapai tujuannya. Guna memperoleh Sumber Daya Manusia yang berkualitas dan sesuai dengan kebutuhan perusahaan maka dibutuhkan proses rekrutmen dan seleksi yang baik dan benar. Penelitian ini bertujuan untuk mendeskripsian proses rekrutmen dan seleski karyawan PT.Pancara Belantara Indah. Pengumpulan data menggunakan metode wawancara. Penentuan informasi menggunakan metode Purposive sampling. Berdasarkan hasil penelitian didapatkan bahwa proses rekrutmen karyawan menggunakan metode rekrutmen internal dan eksternal. Metode rekrutmen internal berasal dari referensi karyawan yang bekerja di perusahaan saat ini, sedangkan metode ekternal menggunakan brosur. Terkait dengan proses seleksi perusahaan menggunakan langkah penerimaan pendahuluan, wawancara seleksi, pemeriksaan referensi-referensi, wawancara dan keputusan langsung oleh bagian umum.
\end{abstract}

Keywords: Rekrutmen, seleksi, metode internal dan Eksternal

\section{PENDAHULUAN}

Pada era globalisasi sekarang ini, perkembangan pesat dalam dunia usaha ditandai dengan semakin banyaknya perusahaan baru yang didirikan. Hal ini menjadi tantangan tersendiri bagi perusahaan-perusahaan yang lebih dahulu terjun dalam dunia usaha. Perkembangan pesat dalam dunia usaha, pada satu sisi dapat meningkatkan kesejahteraan masyarakat tetapi disisi lain perkembangan ini menyebabkan semakin ketatnya persaingan dalam dunia usaha. Semakin ketatnya persaingan disebabkan adanya perubahan-erubahan yang terjadi, seperti kemajuan teknologi dan perubahan perilaku pelanggan yang semakin selektif dalam memilih produk atau jasa yang akan dikonsumsi. Agar perusahaan tetap eksis dalam kalangan masyarakat maka perusahaan tersebut harus memiliki keunggulan kompetitif sehingga pada akhirnya perusahaan mampu memenangkan persaingan yang terjadi (Nugroho, 2006, p.1). 
Rekrutmen, Seleksi,

\section{6}

Pada Penelitian ini penulis membatasi pada pembahasan masalah pengelolaan Sumber Daya Menusia pada faktor rekrutmen dan seleksi. Apabila Faktor-faktor tersebut dijalankan dengan baik dan benar, maka perusahaan akan mendapatkan Sumber Daya Manusia yang berkualitas, berkompeten dan memiliki kemampuan atau skill yang sesuai dengan standar pekerjaan sehingga kinerja perusahaan dapat menjadi optimal.

Proses rekrumen tenaga kerja yang sukses dapat mempengaruhi fungsi-fungsi dan aktivitas Manajemen Sumber Daya Manusia lain yang dilakukan setelah proses rekrutmen selesai. Oleh karena itu, proses rekrutmen harus dilakukan dengan sangat serius dan hati-hati. Demikian juga dengan proses seleksi yang mendapatkan perhatian penting dari perusahaan karena seleksi merupakan tempat awal untuk membangun kuallitas kedalam organisasi. Dengan demikian peran rekrutmen dan seleksi dalam sebuah organisasi sangatlah penting karena turut menentukan keberhasilan organisasi dalam mencapai tujuannya.

Rekrutmen dan seleksi pada karyawan juga dilakukan oleh PT Pancaran Belantara Indah. Seringkali perusahaan mengalami kesulitan dalam mendapatkan Sumber Daya Manusia yang tepat. Hal ini terjadi karena seringkali terjadi pengunduran diri dengan berbagai alasan. Berbagai kasus pengunduran diri dilakukan oleh karyawan salahsatunya karena merasa kurangnya kemampuan karyawan dalam memenuhi tugas dan tanggung jawab dalam pencapaian yang ditetapkan oleh perusahaan. Hal ini disebabkan proses rekrutmen dan seleksi yang dilakukan PT. Pancaran Belantara Indah tergolong simpel dan kurang ketat dalam menyeleksi mana tenaga kerja yang berkompeten dan mana yang tidak.

Berdasarkan latar belakang diatas, penulis ingin membahas secara khusus bagaimana proses rekrutmen dan seleksi karyawan pada PT. Pancaran Belantara Indah dalam aspek rekrutmen dan seleksi. 


\section{KAJIAN TEORITIS}

Rekrutmen, Seleksi,

Manajemen Sumber Daya Mausia merupakan ilmu Manajemen yang aktivitas manajemen yang diakukan dengan tujuan merangsang, mengembangkan, memotivasi, dan memelihara kinerja yang tinggi didalam organisasi.

Marwansyah (2012), menejemen sumber daya manusia dapat diartikan sebagai pendayagunaan sumber daya manusia didalam organisasi, yang dilakukan melalui fungsi-fungsi perencanaan sumber daya manusia, rekrutmen dan seleksi. Pengembangan sumber daya manusia, perencanaan dan pengembangan karir, pemberian kompensasi dan kesejahteraan, keselamatan dan kesehatan kerja dan hubungan industrial.

Menurut Amstrong (2008), Menejemen Sumber Daya Manusia didefinisikan sebagai pendekatan strategis dan koheren dengan pengelolaan aset yng paling berharga didalam organisasi, yaitu orang-orang yang bekerja disana yang individual dan kolektif memberikan kontribusi pada pencapaian tujuannya.

Sastrohadiwiryo (2002) menggunakan istilah manajemen tenaga kerja sebagai penganti manajemen sumber daya manusia. Menurutnya, manajemen tenaga kerja merupakan pendayagunaan, pembinaan, pengaturan, pengurusan, pengembangan unsur tenaga kerja baik yang berstatus sebagai buruh, karyawan, maupun pegawai dalam usaha mencapai hasil guna yang sebesar besarnya, sesuai dengan harapan usaha perorangan, badan usaha, lembaga, maupun instansi.

Dari beberapa pendapat ahli diatas, dapat disimpulkan bahwa manajemen sumber daya manusia adalah proses perencanaan, pengorganisasian, pelaksanaan dan pengontrolan terhadap sumberdaya manusia dalam oganisasi untuk mencapai tujuan perusahaan untuk mencapai tujuan perusahaan.

Menurut Sulistiyani dan Rosidah (2009), rekrutmen adalah proses mencari, menemukan, dan menarik para pelamar untuk menjadi pegawai pada dan oleh organisasi tertentu atau sebagai serangkaian aktivitas mencari dan memikat pelamar kerja dengan motovasi, kemapuan, keahlian dan pengetahuan yang diperlukan guna menutupi kekurangan yang diidentifikasi dalam perencanaan kepegawaian.

Menurut Batemen dan snell (2007), perekrutan membantu meningkatkan sekumpulan calon yang mungkin dipilih untuk pekerjaan, rekrutmen internal organisasi (mengingat karyawan untuk promosi dan transfer) atau eksternal. 
Rekrutmen, Menurut marwansyah (2012), proses rekrutmen dapat dilakukan melalui perencanaan sumber daya mausia dapat diketahui kesenjangan antara kebutuhan atau permintaan tenaga kerja dengan ketersediaan tenaga kerja, baik dari segi jumlah maupun mutu atau kualifikasi. Setelah jabatan kosong ditentukan, perlu ditetapkan pula persyaratan jabatan. Apabila analisis jabatan sudah pernah menghasilkan dokumen spesifikasi jabatan, langkah ini tidak diperlukan lagi. Bila sebuah organisasi memutuskan untuk melakukan rekrutmen maka ada dua pilihan sumber rekrutmen yaitu dari dalam dan luar organisasi itu sendiri.

Sumber-sumber rekrutmen bisa berasal dari Internal maupun eksternal

\section{A. Sumber Internal}

Sumber internal menurut hasibuan (2008) adalah karyawan yang akan mengisi lowongan kerja yang diambil dari dalam perusahaan tersebut. Hal ini dapat dilakukan dengan cara melakukan mutasi atau memindahkan karyawan yang memenuhi spesifikasi jabatan atau pekerjaan tersebut. Pemindahan karyawan bersifat vertikal (Promosi atau demosi) maupun bersifat horizontal. jIka masih ada karyawan yang memenuhi spesifikasi pekerjaan, sebaiknya perusahaan mengambil dari dalam perusahaan khususnya untuk jabatan manajerial. Hal ini sangat penting untuk memberian kesempatan promosi bagi karyawan yang ada. Adapun kebaikan dari sumber internal adalah:

1. Tidak terlalu mahal

2. Dapat memelihara loyalitas dan mendorong motivasi karyawan yang ada

3. Karyawan telah terbiasa dengan suasana dan budaya perusahaan.

Sedangkan kelemahan dari sumber internal yaitu :

1. Pembatasan bakat-bakat

2. Mengurangi peluang

3. Dapat meningkatkan puas diri

Adapun sumber-sumber internal melalui :

1. Penawaran terbuka untuk jabatan (Job Posting Program)

Rekrutmen terbuka ini merupakan sistem mencari pekerjaan yang memiliki kemampuan yang tinggi untuk mengisi jabatan yang kososng dengan memberikan kesempatan kepada semua karyawan yang berminat.

2. Perbantuan Pekerja (Departing Employees) 
Rekrutmen ini dapat dilakukan melalui perbantuan pekerja untuk suatu jabatan

Rekrutmen, dari unit kerja lain.

\section{B. Sumber eksternal}

Menurut Hasibuan (2008) mengatakan bahwa sumber eksternal adalah karyawan yang akan mengisi jabatan yang lowong yang dilakukan perusahaan dari sumbersumber yang berasal dari luar perusahaan. Sumber-sumber eksternal berasal dari:

1. Kantor penempatan tenaga kerja

2. Lembaga-lembaga pendidikan

3. Referensi karyawan atau rekan kerja

4. Serikat-serikat buruh

5. Pencangkokan dari perusahaan lain

6. Nepotisme atau leasing

7. Pasar tenaga kerja dengan memasang iklan melalui media massa

8. Dan Sumber-sumber lainnya

T. H. Handoko (1995) tahap-tahap seleksi tenaga kerja yang dilakukan oleh suatu organisasi

1. Penerimaan pendahuluan

Jika pelamar datang sendiri, maka wawancara pendahuluan dapat dilakukan. Hal ini dapat membantu menghilangkan kesalahpahaman dan menghidar pencarian informasi dari sumber tidak resmi.

2. Tes-tes penerimaan

Tes-tes penerimaan adalah berbagai peralatan bantu yang menilai kemungkinan padunya antara kemampuan, pengalaman dan kepribadian pelamar dan persyaratan jabatan. Agar tes dapat meloloskan para pelamar yang tepat, maka ia harus valid, dimana skor-skor tes memiliki hubungan yang signifikan dengan prestasi kerja atau kriteria-kriteria relevan lainnya. Selain tes validasi, ada juga tes validitas, juga ada tes reliabilitas yang seharusnya menghasilkan skor-skor yang konsisten setiap waktu seorang pelamar melakukannya. Jika hasil tes sangat bervariasi karena skor yang baik 
Rekrutmen, Seleksi, tergantung pada "nasib" maka tes tidak reliabel. Suatu tes disebut reliabel jika memiliki tingkat konsistensi yang tinggi.

Macam-macam tes seleksi ada 3, yaitu:

1. Tes Psikologi (Psychological Test)

Adalah berbagai peralatan tes yang mengukur atau neguji kepribadian atau tempramen, bakat, minat, kecerdasan dan keinginan berprestasi.

a. Tes Kecerdasan (Intelligence test) Adalah menguji kemampuan mental pelamar dalam hal daya pikir secara menyeluruh dan logis. B. Tes Kepribadian (Personality Test) adalah kesediaan bekerjasama, sifat kepemimpinan, dan unsur-unsur kepribadian lainnya. C. Tes Bakat (Aptitude Test) adalah mengukur potensial pelamar yang dapat dikembangkan. D. Tes Minat (Interest test) Adalah mengukur antusiasme pelamar terhadap semua jenis pekerjaan. E. Tes Prestasi (Achievement test) adalah mengukur kemampuan pelamar sekarang.

2. Tes Pengetahuan (Knowledge Test) yang menguji informasi atau pengalaman yang dimiliki pelamar. Pengetahuan yang diujikan harus sesuai dengan kebutuhan untuk melaksanakan pekerjaan.

3. Test Performa (Performa Test) Bentuk tes yang mengukur kemapuan para pelamar untuk melaksanakan beberapa bagian pekerjaan yang akan dipegangnya.

3. Wawancara seleksi

Wawancara selekksi adalah percakapan formal dan mendalam yang dilakukan untuk mengevaluasi hal dapat diterima atau tidak diterimanya seorang pelamar. Tujuan utama wawancara adalah untuk menghimpun informasi bagi pembuat keputusan seleksi. Bila wawancara dikembangkan secara cermat maka dapat membuatnya mungkin untuk mencapai tingkat keandalan yang dapat diterima. Adapun tujuan wawancara tersebut adalah:

a. Informasi megenai pelamar, 
karena informasi yang diperoleh lewat alat seleksi lain mungkin tidak lengkap, wawancara memberikan kesempatan bagi informasi aktual untuk

Rekrutmen, dijernihkan dan diinterprestasikan.

b. Menjual perusahaan

Wawancara pekerjaan membuka kesempatan lebar bagi pewawancara untuk meyakinkan sipelamar bahwa oragnisasi tersebut merupakan tempat yang baik untuk kerja. Dalam mempromosikan perusahaan pewawancara tidak boleh melebih-lebihkan, melainkan memberikan gambaran yang realistik mengenai kelebihan dan kelemahan perusahaan.

c. Informasi mengenai perusahaan

Selama wawancara, informasi umum mengenai perusahaan kebijakan dan kesempatan kerja dijelaskan terhadap pelamar, pewawancara perlu untuk mengarahkan pelamar terhadap jenis kesempatan didala perusahaan diamana dia mungkin cocok.

d. Menjalin persahabatan

Wawancara harus mewakili hubungan antar pribadi yang bersahabat. Pada saat pewawancara dan pelamar mengakhiri wawancara, kedua belah pihak hendaknya berpisah dengan perasaan bahwa mereka adalah sahabat.

Wawancara seleksi memiliki dua kelemahan utama, yaitu reliabilitas dan validitas. Pelaksanaan wawancara sering menghasilkan informasi yang bervariasi dari satu pewawancara dengan pewawancara yang lain. Reabilitas dapat ditingkatkan jika perusahaan menggunakan pertanyaan identik yang telah ditentukan sebelumnya dan pewawancara dilatih untuk melaporkan tanggapan- tanggapan pelamar secara sistematik. Berikut adalah bentuk kesalahan dalam wawancara:

1. Hallo effect Misalnya, seorang pelamar yang mempunyai senyuman menarik dan simpatik diperlakukan sebagai calon unggul sebelum wawancara dimulai. Atau seorang pelamar yang menggunakan blue jeans dalam wawancara ditolak secara mentah.

2. Leading question misalnya, apakah anda setuju bahwa laba adalah penting? Apakah saudara akan menangani pekerjaan ini? 
Rekrutmen, Seleksi,

\section{2}

4. Pemeriksaan Referensi-referensi

Personal references biasanya diberikan oleh keluarga atau teman-teman terdekat baik yang ditunjuk oleh pelamar sendiri atau diminta oleh perusahaan. Jika referensi diserahkan tertulis, pemberi referensi biasanya hanya menekankan hal-hal positif. Oleh karena itu referensi pribadi pada umumnya jarang digunakan. Employment references berbeda dengan referensi pribadi karena mencakup latar belakang atau pengalaman kerja pelamar.

5. Evaluasi medis (Tes Kesehatan)

Evaluasi ini mengharuskan pelamar untuk melakukan tes kesehatan baik dilakukan oleh dokter diluar perusahaan maupun oleh tenaga medis perusahaan itu sendiri. Evaluasi medis memungkinkan perusahaan untuk menekankan biaya perawatan kesehatan karyawan dan asuransi jiwa, mendapatkan karyawan yang memenuhi persyaratan kesehatan fisik untuk pekerjaan-pekerjaan tertentu atau memperoleh karyawan dapat mengatasi stres fsik dan mental suatu pekerjaan.

6. Wawancara oleh penyelia

Atasan langsung (penyelia) pada akhirnya merupakan orang yang bertanggung jawab atas para karyawan baru yang diterima. Oleh karena itu pendapat dan persetujuan mereka harus diperhatikan untuk keputusan penerimaan final. Penyelia memiliki kemapuan untuk mengevaluasi 
kecakapan teknis pelamar dan menjawab pertanyaan-pertanyaan dari pelamar tentang pekerjaan tertentu secara lebih tepat.

Rekrutmen, Seleksi,

7. Keputusan penerimaan

Apakah diputuskan oleh atasan langsung atau departemen sumber daya manusia, keputusan penerimaan menandai berakhirnya proses seleksi. Dari sudut pandang hubungan masyarakat para pelamar yang ditolak harus diberitahu dan dapat mempertimbangkan lagi para pelamar yang ditolak untuk lowongan-lowongan pekerjaan lainnya yang mungkin sesuai (dalam Sunyoto,Danang,2012).

Menurut Malayu S.P Hasibuan (2002:47) Seleksi adalah suatu kegiatan pemilihan danpenetuan pelamar yang diterima atau ditolak untuk menjadi karuawan perusahaan. Seleksi ini didasarkan kepada spesifikasi tertentu dari setiap perusahaan yang bersangkutan.

Menurut Simamora (2004), seleksi merupakan proses pemilihan dari sekelompok pelamar yang paling memenuhi kriteria seleksi untuk posisi yang tersedia di dalam perusahaan. Sedangkan menurut Teguh (2009) menjelaskan bahwa seleksi adalah proses yang terdiri dari berbagai langkah yang spesifik dari kelompok pelamar yang paling cocok dan memenuhi syarat untuk jabatan tertentu. Ada tiga hal yang menyebabkan seleksi menjadi hal yang penting, yaitu: 1. Kinerja seorang manajer tergantung pada sebagian kinerja bawahannya. 2. Seleksi yang efektif penting karena biaya perekrutan yang dikeluarkan oleh perusahaan dalam pengangkatan pegawai tidak sedikit. 3. Seleksi yang baik itu penting karena implikasi hukum dari pelaksanaannya secara serampangan. Berdasarkan dari beberapa pengertian diatas menurut beberapa para ahli maka dapat dipahami bahwa seleksi merupakan suatu kegiatan pemilihan dan penentuan pelamar yang diterima atau ditolak untuk menjadi karyawan perusahaan. Seleksi ini didasarkan kepada spesifikasi tertentu dari setiap perusahaan-perusahaan yang bersangkutan

\section{METODE PENELITIAN}

Jenis penelitian ini termasuk dalam jenis penelitian kualitatif deskriptif. Mnurut Saryono (2010), penelitian kualitatif adalah penelitian yang digunakan untuk menyelidiki, menemukan, menggambarkan dan menjelaskan kualitas atau keistimewaan 
Rekrutmen, Seleksi,

dari pengaruh sosial yang tidak dapat dijelaskan, diukur atau digambarkan melalui pendekaatan kuantitatif. Menurut Muktar (2013). Penelitian deskriptif adalah penelitian yang dimaksud untuk mengumpulkan informasi mengenai subyek peneliti dan perilaku subyek penelitian pada suatu periode tertentu. Penelitian kualitatif deksriptif berusaha mendeskripsikan seluruh gejala atau keadaan yang ada, yaitu keadaan gejala menurut apa adanya pada saat penelitian dilakukan.

Obyek penelitian kualitatif adalah objek yang bersifat alamiah, berkembang apa adanya, tidak dimanipulasi dan kehadiran peneliti tidak begitu mempengaruhi dinamika pada objek tersebut (Sugiyono, (2009). Dalam penelitian ini penulis akan melakukan penelitian pada perusahaan PT. Pancaran Belantara Indah yang mempunyai kualifikasi lapangan usaha Perdagangan besar atas dasar balas jasa (Fee) atau kontrak.

Penentuan narasumber dalam penelitian ini menggunakan teknik Purposive Sampling. Menurut Sugiyono (2011). Purposive Sampling adalah teknik penentuan sampel atas pertimbangan tertentu. Teknik ini paling cocok digunakan untuk penelitian kualitatif yang tidak mealkukan generalisasi. Pada penelitian ini, penulis memilih narasumber-narasumber berdasarkan kriteria memiliki pengetahuan dan terlibat langsung dalam proses rekrutmen dan seleksi yang dilakukan PT. Pancaran Belantara Indah. Berikut adalah narasumber yang dipilih oleh penulis:

1. Narasumber 1: Djusni (Direktur Utama)

2. Narasumber 2: Tjiptana Adji Djusnaedi , S.E (Direktur)

3. Narasumber 3: Darwina Srinovita ( Manajer Bagian Umum)

Pada penelitian ini, sumber data yang digunakan adalah data primer dan sekunder. Data Primer dikumpulkan oleh peneliti untuk menjawab pertanyaan-pertanyaan penelitian. Data primer yang digunakan dalam penelitian ini adalah hasil wawancara dengan narasumber. Sedangkan data sekunder yang digunakan peneliti dalam penelitian ini adalah berupa Company Profile PT. Pancara Belantara Indah.

Teknik yang digunakan untuk pengumpulan data dalam penelitian ini adalah wawancara. Pada penelitian ini menggunakan jenis wawaancara semistruktur. Jenis wawancara ini termasuk dalam kategori in-dept interview, dimana pelaksanaannya lebih fleksibel bila dibandingkan dengan wawancara terstruktur. Tujuan wawancara jenis ini adalah untuk menemukan permasalahan secara terbuka, dimana pihak yang diajak wawancara diminta untuk mengemukakan pendapat dan ide-idenya. 
Pada penelitian ini, metode yang digunakan untuk menguji keabsahan data adalah metode trianggulasi. Teknik analisa data yang digunakan dalam penelitian ini adalah teknik analisa model Miles dan Huberman (1984)

\section{PEMBAHASAN}

PT. Pancaran Belantara Indah adalah perusahaan yang mempunyai kualifikasi lapangan usaha Perdagangan besar atas dasar balas jasa (Fee) atau kontrak dengan berdiri pada tahun 2013 dengan nomor Tanda Daftar Perusahaan (TDP) 10.04.1.46.00269 alamat perusahaan Jl. H. Achmad Adnawijaya No. 11 Pandu Raya RT 005 RW. 015. Kel. Bantarjati Kec. Bogor Utara Kota Bogor. Selama beroperasi PT. Belantara Indah Bogor telah banyak bekerjasama dengan perusahaan-perusahaan ternama seperti PT. Adhi Karya, PT. Wijaya Karya, PT. Waskita Karya dan PP. Pembangunan Perumahan. Adapun bentuk kerjasama dengan perusahaan-perusahaan tersebut antara lain Pengadaan barang yaitu berupa Kayu dan besi dengan berbagai jenis maupun ukuran. Dalam menjalankan usahanya PT. Pancaran Belantara Indah mempunyai struktur organisasi dapat dilihat pada gambar 1.1

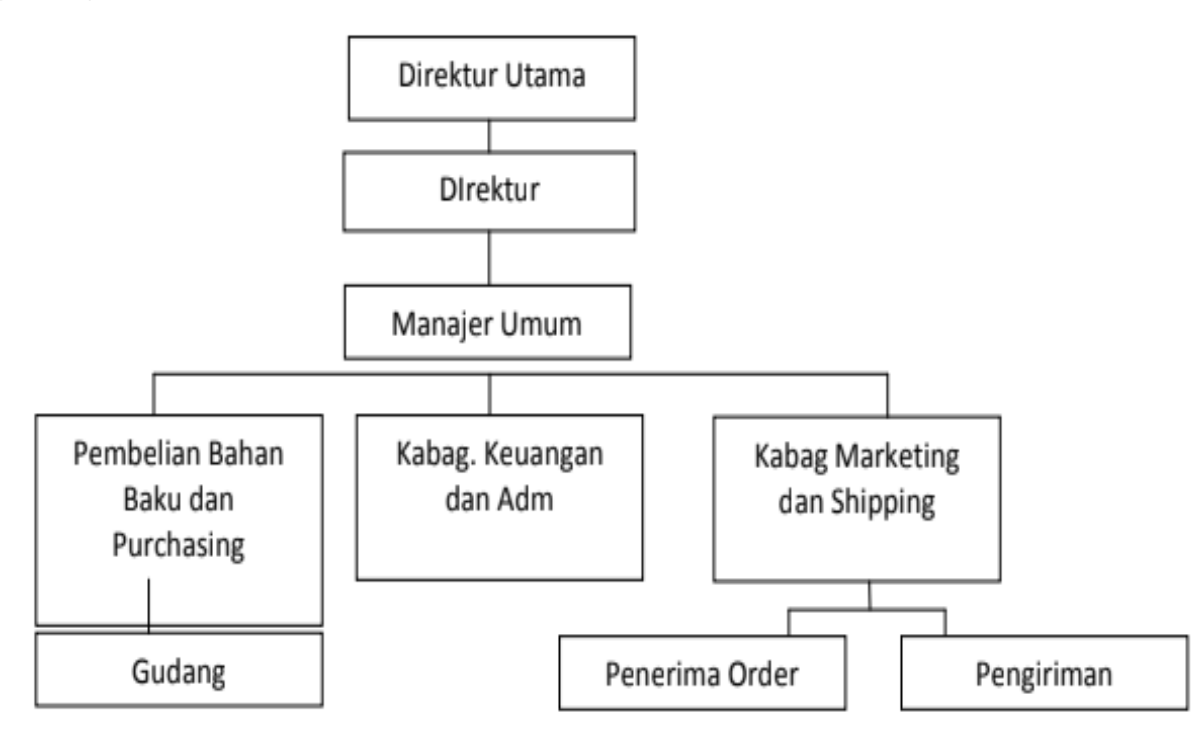

Gambar 1.1 Struktur Organisasi PT, Pancaran Belantara Indah.
Rekrutmen, Seleksi, 
Rekrutmen, Seleksi,
Berdasarkan hasil wawancara dengan narasumber

\section{6}

\section{Rekrutmen}

1. Penentuan Jabatan yang kosong

Berdasarkan hasil wawancara dengan narasumber proses rekrutmen dilakukan apabila terdapat kurangnya jumlah karyawan atau terdapat pengunduran diri dari karyawan. Proses rekrutmen dilaksanakan oleh bagian umum dan diawasi langsung oleh Direktur

2. Penentuan Persyaratan Jabatan

Menurut narasumber bahwa dalam melakukan proses rekrutmen, PT Pancaran Belantara Indah memiliki persyaratan pendidikan minimal D3 diharapkan lulusan tersebut lebih mudah untuk diberikan petunjuk.

3. Penentuan sumber dan metode rekrutmen

Menurut narasumber hasil wawancara dimulai secara internal terlebih dahulu dengan melakukan komunikasi secara langsung dengan karyawan yang ada. Apabila ada yang berminat dari sumber internal tersebut maka perusahaan meminta calon karyawan tesebut untuk datang mengajukan lamaran secara langsung.

Selanjutnya rekrutmen melalui sumber eksternal dilakukan dengan cara melalui postingan bentuk brosur penyebarannya diwilayah sekitar Perusahaan karena diharapkan calon dari karyawan tersebut dalam menempuh jarak ke Perusahaan tidak terlalu jauh.

1) Seleksi

1. Penerimaan Pendahuluan

Berdasarkan hasil wawancara degan narasumber proses seleksi yang dilakukan yaitu dengan melakukan proses penerimaan pendahuluan berupa wawancara secara singkat atau overview kepada para pelamar yang datang langsung seperti perkenalan tentang pribadi pelamar.

2. Tes-tes penerimaan

Berdasarkan hasil wawancara dengan narasumber perusahaan tidak melakukan proses tes seperti tes psikologi, tes pengetahuan dan tes performa. Hal ini 
dilakukan perusahaan karena perusahaan sudah ada gambaran mengenai kemampuan pelamar melalui hasil dari pendidikan terakhir pelamar.

Rekrutmen, Seleksi,

3. Wawancara seleksi

Berdasarkan hasil wawancara dengan narasumber para pelamar melakukan wawancara secara formal memberikan kesempatan pelamar untuk mempresentasikan kemampuan diri pelamar dengan memperhatian bahasa, gaya bicara dan waktu yang digunakan.

\section{Pemeriksaan referensi-referensi}

Berdasarkan hasil wawancara dengan narasumber dalam melakukan proses pemeriksaan referensi-referensi yang meliputi latar belakang para pelamar seperti umur, pendidikan, pengalaman kerja dan lain lain kemudian disesuaikan dengan dokumen-dokumen yang sudah diserahkan pelamar pada perusahaan.

5. Evaluasi Medis

Berdasarkan hasil wawancara dengan narasumber perusahaan tidak melakukan evaluasi medis, evaluasi dilakukan pada wawancara dengan memperhatikan kondisi fisik pada saat wawancara dan riwayat kesehatan karyawan diharapkan riwayat kesehatan yang ada pada pelamar adalah riwayat kesehatan yang baik.

6. Wawancara oleh penyelia

Berdasarkan hasil wawancara dengan narasumber perusahaan tidak melakukan wawancara penyelia karena didalam perusahaan wawancara hanya dilakukan oleh bagian umum.

\section{Keputusan penerimaan}

Berdasarkan hasil wawancara dengan narasumber bahwa para pelamar yang terseleksi akan diambil beberapa penilaian diantaranya pertamakali jurusan yang sesuai, nilai IPK tertinggi, penyampaian dalam mempresentasikan kemampuan diri dan berpenampilan menarik. 
Rekrutmen, Seleksi,

Dalam penelitian ini penulis menggunakan teori rekrutmen yang dikemukakan oleh Marwansyah (2012). PT. Pancara Belantara Indah yang diteliti oleh penulis melakukan tahapan rekrutmen dalam penentuan posisi pekerjaan yang dibutuhkan dengan cara melihat ada atau tidaknya karyawan pada posisi tersebut, adapun jika terjadi kekososongan posisi dikarenakan adanya pengunduran diri karyawan sebelumnya. Proses rekrutmen yang dilakukan perusahaan melalui sumber internal dan eksternal. Sumber yang paling sering didapat perusahaan PT. Pancara Belantara Indah yaitu Sumber dari Internal melalui referensi dari karyawan yang ada tujuan perusahaan supaya para calon karyawan mempunyai tanggung jawab moril terhadap orang yang memberikan referensi tersebut. Selanjutnya proses seleksi teori yang digunakan oleh penulis adalah teori T.H. Handoko (1995), Menurutnya proses seleksi dilakukan melaui 7 tahapan, namun pada perusahaan PT. Pancaran Belantara Indah hanya menerapkan 5 tahapan yaitu penerimaan pendahuluan, wawancara seleksi, Pemeriksaan referensireferensi, evaluasi medis dan Keputusan peneriman.

\section{KESIMPULAN DAN SARAN Kesimpulan}

Berdasarkan hasil pembahasan mengenai proses rekrutmen dan seleksi karyawan pada PT.

Pancaran Belantara Indah dapat disimpulkan bahwa:

1. Proses rekrutmen dan seleksi karyawan dilakukan pada saat terdapat posisi yang kosong pada pekerjaan tertentu yang diakibatkan adanya pengunduran diri dari karyawan sebelumnya.

2. Proses rekrutmen pada PT. Pancaran Belantara indah tidak menekankan pengalaman hanya lebih memfokuskan pada pendidikan terakhir pelamar sehingga seringkali terjadi ketidakpemahaman pada bidang pekerjaan tersebut.

3. Karyawan yang terseleksi dalam melakukan tugasnya dalam minggu pertama di dampingi oleh Manajer bagian umum sehingga berdampak terhadap keterlambatan dalam operasional perusahaan.

4. Pihak yang bertanggung jawab dalam proses rekrutmen adalah bagian umum. 
5. Metode rekrutmen yang digunakan perusahaan menggunakan metode internal dan eksternal.

Rekrutmen, Seleksi,

6. Beberapa pelamar banyak didapat dari internal perusahaan yaitu karyawan yang ada, pelamar membuat surat lamaran dan diantar langsung oleh pelamar.

7. Perusahaan hanya menjalankan proses seleksi sebanyak 5 tahapan yaitu penerimaan pendahuluan, wawancara seleksi, Pemeriksaan referensi-referensi, evaluasi medis dan Keputusan peneriman.

\section{Saran}

Berdasarkan hasil pembahasan mengenai proses rekrutmen dan seleksi karyawan PT. Pancaran Belantara Indah , penulis ingin memberikan saran-saran yang diharapkan dapat berguna bagi perusahaan PT. Pancara Belantara Indah.

1. Proses penerimaan seleksi sebaiknya dilakukan secara lengkap sesuai dengan teori yang di kemukakan oleh T. H. Handoko (1995) meliputi penerimaan pendahuluan, tes-tes penerimaan, wawancara seleksi, pemeriksaan referensireferensi, evaluasi medis, wawancara oleh penyelia, dan keputusan langsung yang dilakukan oleh penyelia.

2. Dalam proses rekrutmen sebaiknya perusahaan mencoba untuk mengambil pelamar dari eksternal perusahaan.

3. Tes-tes medis sebaiknya dilakukan oleh perusahaan dengan tujuan meminimalisir kemungkinan-kemungkinan biaya-biaya tak terduga seperti biaya kesehatan dan mengurangi tingkat ketidak hadiran karyawan.

\section{DAFTAR PUSTAKA}

Armstrong, Michael (2008). Strategic Human Resaurce Management : A Guide to Action ( $4^{\text {th }}$ ed). London : Kogan Page Limited

Ambar, Teguh Sulistiyani dan Rosidah, Manajemen Sumber Daya Manusia,.

(Yogyakarta :

Graha Ilmu). 2009

Batemen, Thomas S. \& Snell, Scott A. (2007). Management : Leading \& Collaborating in a 
Rekrutmen, Seleksi,

Competitive World (7th ed). New York : The McGraw-Hill Companies,Inc.

Hasibuan, Malayu S.P. 2008. Manajemen Sumber Daya Manusia. Cetakan ke-11.

Jakarta: PT.Bumi Aksara

Handoko, TH. Tahap-tahap Seleksitenaga kerja. Manajemen Sumber

Daya Manusia. Yogyakarta: CAPS (Center for Academic Publishing Service),

070 1995. 111.

Marwansyah (2012). Manajemen Sumber Daya Manusia, Edisi Kedua Bandung:

Alfabeta.

Malayu S.P. Hasibuan. (2002). Managemen Sumber Daya Manusia. Bandung: Bumi.

Aksara. Mukhtar. 2013. Metode Praktis Penelitian Deskriptif Kualitatif. Jakarta:

REFERENSI (GP Press Group).

Milles, M.B. and Huberman, M.A. 1984. Qualitative Data Analysis London: Sage

Publication.

Nugroho, R. (2006). Analisis faktor-faktor yang mempengaruhi kinerja karyawan.

Universitas Diponegoro.Semarang.

Saryono. 2010. Metodologi Penelitian Kualitatif dalam bidang kesehatan Yogyakarta:

Muha Medika.

Sastrohadiwiryo, B. Siswanto. 2002. Manajemen Tenaga kerja Indonesia :

Pendekatan administratif dan operasional. Jakarta: Bumi Aksara

Simamora, Henry. 2004. Manajemen Sumber Daya Manusia. Yogyakarta:

Sulistiani and Rosidah. Pengertian Penarikan Tenaga Kerja. Manajemen Sumber Daya

Manusia. Yogyakarta: CAPS ) Center for Academic Publishing Service), 2009.93

Sunyoto, Danang (2012). Manajemen Sumebr Daya Manusia. Yogyakarta: CAPS

(Center for Academic Publishing Service), 2002.1.

Sugiyono. (2009). Metode Penelitian Bisnis (Pendekatan Kualitatif dan R\&D). Bandung : CV Alfabeta.

Sugiyono. (2011) Statistika untuk Penelitin. Bandung: Alfabeta. 